\title{
Intake, digestibility, rumen characteristics and microbial protein synthesis efficiency in bovine and bubaline fed sugar cane silage with additives
}

\section{Emilyn Midori Maeda ${ }^{1,4}$, Lucia Maria Zeoula 2,5 , Clóves Cabreira Jobim²,5, Ulysses Cecato², Luiz Paulo Rigolon ${ }^{2}$, Ricardo Kazama ${ }^{1}$, Guido Jacobi ${ }^{3}$, Acir Felipe Grolli Carvalho ${ }^{4}$}

\author{
1 Programa de Pós Graduação em Zootecnia - UEM, Maringá-PR \\ 2 Departamento de Zootecnia - UEM, Maringá-PR. \\ ${ }^{3}$ Curso de Graduação em Zootecnia. Scholar from PIBIC - UEM, Maringá-PR. \\ 4 Universidade Tecnológica Federal do Paraná/UTFPR, Dois Vizinhos-PR. \\ ${ }^{5}$ Researcher from CNPq.
}

\begin{abstract}
Intake and total and ruminal digestibility, ruminal characteristics and microbial synthesis efficiency in bovine and bubaline fed sugar cane silages treated with microbial additive Lactobacillus buchneri (inoculate) and the addition of: cassava byproduct meal at $250 \mathrm{~g} / \mathrm{kg}$; soybean hulls at $250 \mathrm{~g} / \mathrm{kg}$; and urea at $33 \mathrm{~g} / \mathrm{kg}$, in natural matter were evaluated. The forage:concentrate ratio was 600:400 g/ $/ \mathrm{kg}$. Bubaline body weight (BW) was $403 \pm 49 \mathrm{~kg}$ and bovine BW was $492 \pm 10 \mathrm{~kg}$. The experimental design consisted of two $4 \times 4$ Latin squares in a $4 \times 2$ factorial arrangement. The average DM intake did not differ between species, and the diet with urea showed lowest intake $(13 \mathrm{~g} / \mathrm{kg} \mathrm{BW})$. Among the diets, the one with soybean hulls addition increased the total digestibility of DM, organic matter (OM) and neutral detergent fiber (NDF), while addition of urea reduced the DM, OM and non-fibrous carbohydrates (NFC) total digestibility in both species. Bovines have higher ruminal digestibility of NFC in the diet with addition of inoculate, inoculate + soybean meal and inoculate + urea diets than bubaline. Ruminal liquid pH was higher for bubaline (6.61) than bovines (6.48). Diets with addition of cassava byproduct and soybean hulls presented higher ruminal short chain fatty acids concentrations. Ruminal ammonia concentration $\left(\mathrm{N}-\mathrm{NH}_{3}\right)$ did not differ between species and the treatment with urea presented the highest value of $\mathrm{N}-\mathrm{NH}_{3}(17.25 \mathrm{mg} / 100 \mathrm{~mL})$. Liquid passage rate was higher for bubaline $(12.9 \% / \mathrm{h})$ than bovines $(9.9 \% / \mathrm{h})$. Bubaline has higher microbial synthesis efficiency than bovine: 35.1 vs $24.6 \mathrm{~g}$ of $\mathrm{N}$-microbial $/ \mathrm{kg} \mathrm{OM}$ of the total rumen digestibility, regardless of the diet.
\end{abstract}

Key Words: Lactobacillus buchneri, ruminal ammonia, short chain fatty acids, soybean hulls, urea

\section{Introduction}

Sugar cane is an alternative source as forage supplement due to its great potential of green mass production ( $60 \mathrm{t}$ to $120 \mathrm{t} / \mathrm{ha}$ ), low cost to produce a ton of dry matter and an alternative feed in times of pasture shortage. The sugar cane energetic value is preserved until six months after maturation (Silva, 1993). Traditionally, sugar cane is served in natural matter; however, logistical and operational advances foment the use of sugar cane silage due to the extended conservation time (Nussio \& Schmidt, 2004).

Sugar cane is highly productive with low cost to be ensiled, compared with corn/area unit (Anualpec, 2006). To facilitate farm organisational systems by reducing labor, increase plant regrowth and stalk longevity, it is important to ensile the sugar cane at the most nutritional value stage of the plant (Nussio \& Schmidt, 2004).

However, sugar cane has nutritional limitations, such as low values of proteins and minerals (e.g. phosphorus).
The sugar cane ensilage causes alcoholic fermentation due to high levels of soluble carbohydrates. Thus, it is not recommended to use sugar cane exclusively in natural matter or ensiled (Thiago \& Vieira, 2006).

The availability of sugar cane nutrients is limited due to the indigestible compounds found in the cell wall; there are recommendations for the use of chemical treatments and association of sugar cane feed with additives and concentrates. Carbohydrates, bran and grain sources are also utilised to increase dry matter (DM) content, to reduce liquid waste and increase nutritional values in the sugar cane silage (McDonald et al., 1991).

Soybean hulls and cassava byproduct meal are important sources of concentrate due to great values of DM and easy access and availability in Brazil. The combined use of concentrates with sugar cane silage are recommended to increase forage nutritional value.

Information regarding sugar cane ensiling technology is crucial to answer questions related to the fermentative process of sugar cane in association with chemical additives, 
agricultural byproducts, urea, and to understand the effects in rumen ecology of bovine and bubaline.

The objective of this experiment is to evaluate feed intake, total and partial digestibility, rumen $\mathrm{pH}, \mathrm{N}-\mathrm{NH}_{3}$ and short-chain fatty acids rumen concentrations, liquid phase dynamics and microbial synthesis efficiency in bovine and bubaline fed sugarcane silage associated with different additives.

\section{Material and Methods}

The experiment was conducted at Experimental Farm of Iguatemi (FEI); chemical analysis was performed at Laboratory of Analysis of Food and Animal Nutritional from the Department of Animal Science at Universidade de Maringa - UEM, Paraná State, and Laboratory of Bromatology at Universidade de Sao Paulo da Escola Superior de Agricultura “Luiz de Queiroz” (USP/ESALQ).

Four three-year-old male castrated Holstein bovine and four two-year-old male castrated crossbred buffaloes, all fistulated in the rumen, $492 \pm 10 \mathrm{~kg}$ and $403 \pm 49 \mathrm{~kg}$ body weight (BW), respectively, were used. Animals were kept in individual stalls, with concrete floor, individual feeder and water supply.

Diets were composed of sugarcane silage additives and crushed corn and soybean meal, in a forage:concentrate ratio of 60:40. Diets were isoprotein and isoenergetic balanced, $120 \mathrm{~g} / \mathrm{kg}$ of crude protein (CP) and $690 \mathrm{~g} / \mathrm{kg}$ of total digestible nutrients (Table 1).

Table 1 - Experimental diet composition (g/kg DM)

\begin{tabular}{lcccc}
\hline Feedstuffs & \multicolumn{4}{c}{ Treatments $(\mathrm{g} / \mathrm{kg})$} \\
\cline { 2 - 5 } & SCSI & SCSIC & SCSIS & SCSIU \\
\hline Soybean meal & 160 & 170 & 130 & 30 \\
Corn & 230 & 220 & 260 & 360 \\
Mineral salt & 10 & 10 & 10 & 10 \\
Roughage & 600 & 600 & 600 & 600 \\
Components (g/kg) & & & & \\
Dry matter & 530.0 & 550.4 & 546.3 & 517.7 \\
Organic matter & 958.4 & 962.2 & 959.8 & 960.3 \\
Crude protein & 116.7 & 119.2 & 118.7 & 117.6 \\
Neutral detergent fiber & 426.3 & 374.8 & 423.3 & 441.8 \\
Acid detergent fiber & 276.9 & 223.7 & 277.7 & 261.0 \\
Ash & 41.6 & 37.8 & 40.2 & 39.7 \\
Ether extract & 19.4 & 18.1 & 19.2 & 21.5 \\
Total carbohydrates & 809.9 & 808.5 & 812.9 & 812.5 \\
Non-fibrous carbohydrates & 394.0 & 447.0 & 404.0 & 383.0 \\
Lignin & 62.5 & 44.7 & 48.6 & 61.5 \\
ADIN & 220.9 & 174.8 & 151.5 & 96.2 \\
NDIN & 238.0 & 197.7 & 219.0 & 107.7 \\
\hline SCSI - saryyyyy & &
\end{tabular}

SCSI - sugar cane silage + inoculate; SCSIC - SCSI + cassava byproduct meal; SCSIS - SCSI + soybean hulls; SCSIU - SCSI + urea.

ADIN - acid detergent insoluble nitrogen ( $\mathrm{g} / \mathrm{kg}$ total $\mathrm{N})$; NDIN - neutral detergent insoluble nitrogen.; DM - dry matter.
Sugar cane was of varietyRB 855156 (precocius), first and early harvested at 11 months, estimate production of 94 tons of green matter per hectare (GM/ha) and $17.9^{\circ}$ Brix. Supplied by COOPERVAL - Agroindustrial Cooperative L total digestibility, in the municipality of Jandaia do Sul, Paraná State, Brazil, sugar cane were transported to FEI for silage confection, harvesting and ensilage were performed on 10 and 13 of June, 2005.

The husked sugar cane was processed at a stationary chopper, regular size of $10 \mathrm{~mm}$. Bacterial inoculant was added at ensilage time following the procedure: solution with heterolactic bacteria Lactobacillus buchneri (strain NCIMB 40788) was sprayed over the chopped cane before filling of silos. Distillate water was utilised following dosage recommendations of $5 \times 10^{4}$ colony-forming units $\mathrm{UFC} / \mathrm{g}$. The control treatment consisted of silage of sugar cane + inoculate.

Agricultural residues were added to the control diet, and soybean hulls (high content of digestible fiber and pectin) and cassava byproduct meal (high content of starch) were mixed in chopped sugar cane at a proportion of $250 \mathrm{~g} / \mathrm{kg}$ of DM, for the making of two other diets (dosage based on Freitas et al., 2002).

The diet with addition of urea was composed of granular urea $450 \mathrm{~g} / \mathrm{kg}$ nitrogen $(33.0 \mathrm{~g} / \mathrm{kg} \mathrm{DM})$ to maximise the protein content of the silage.

Four trench silos of $7000 \mathrm{~kg}$ capacity were built with different additives: sugar cane silage with bacterial inoculant; sugar cane silage with bacterial inoculant + cassava byproduct meal; sugar cane silage with bacterial inoculant + soybean hulls; sugar cane silage with bacterial inoculants + urea.

Sugar cane bagasse was used to cover the soil inside trench silos and plastic canvas was used to cover the sides. The application of additives was done directly on the chopped sugar cane, then compacted with a tractor and covered with the plastic canvas.

After 60 days, silos were opened and used to feed animals twice a day in equal amounts each time: morning $(8 \mathrm{~h})$ and afternoon ( $16 \mathrm{~h})$; forage and concentrate were mixed in the feeder. Animals received daily $50 \mathrm{~g}$ of mineral salt, at a 1:1 mix concentration of salt and commercial supplement.

The experimental design consisted of four periods of 20 days. Each period consisted of 14 days of adaptation and 6 days of sampling. Samples were collected from the first to the fourth day: $400 \mathrm{~mL}$ omasal/day fluid, obtained by suction through reticulum-omasum orifice (Leão et al., 2002). On the first day, sampling was at 8:00 h, on the second day, at 12:00, on the third day, at 16:00, and on the fourth day, at 20:00 h, 
resulting in four samples from each animal at each period. On the last two days, ruminal liquid samples were collected and stored $\left(-20^{\circ} \mathrm{C}\right)$ for posterior fermentation characteristics and microbial production analysis.

During the trial, feed and orts were weighted daily. For posterior analyses, samples were stored in plastic bags and frozen. To estimate nutrients and DM intake, animals were weighted by the end of each adaptation and sampling period.

Chromium oxide $\left(\mathrm{Cr}_{2} \mathrm{O}_{3}\right)$ was used as an external indicator to estimate daily DM flow in the omasal and feces. Five grams of $\mathrm{Cr}_{2} \mathrm{O}_{3}$ wrapped in a paper were directly placed inside the rumen twice a day, at 8:00 and 16:00 h, total 10 grams of $\mathrm{Cr}_{2} \mathrm{O}_{3}$ animal/day during adaptation and sampling for all the periods.

On the fifth day, $70 \mathrm{~mL}$ of rumen fluid were collected through ruminal cannula at times 0 (first feeding) 2, 4, 6, 8 hours after morning feeding. Sample $\mathrm{pH}$ was immediately measured. To determine ammoniacal nitrogen $(\mathrm{N}-\mathrm{NH} 3)$ and short-chain fatty acid concentrations, $50 \mathrm{~mL}$ ruminal fluid were acidified using $1 \mathrm{~mL}$ of sulphuric acid at a 1:1 ratio.

On the fifth day of sampling, before feeding, $30 \mathrm{~g} \mathrm{Co}-$ EDTA were diluted in $500 \mathrm{~mL}$ of distillate water (Uden et al., 1980) and administered in the rumen of the animals. Before infusion, $20 \mathrm{ml}$ ruminal liquid were collected at every two hours until 12 hours after the indicator was administered.

On the last day of each period, $1.5 \mathrm{~kg}$ rumen content was sampled ( 2 hours after feeding), $500 \mathrm{ml}$ of rumen content sample were mixed in $9 \mathrm{~g} / \mathrm{L}$ saline solution $(\mathrm{NaCl})$, homogenized using blender, then filtered in double cloth and stored $\left(-20^{\circ} \mathrm{C}\right)$. Samples were processed according to Cecava et al. (1990). To determine microbial protein omasal rate, purine bases were quantified through technique described by Ushida et al. (1985). Duodenum (g/day) total microbial $\mathrm{N}$ flow was estimated by dividing $\mathrm{N}$ :purine bacteria ratio by $\mathrm{N}$ :purine duodenal digestion and multiplying the coefficient flow by the total microbial $\mathrm{N}$ flow. Microbial synthesis efficiency was express in $\mathrm{g}$ of microbial $\mathrm{N} / \mathrm{kg}$ of rumen degraded organic matter, which was calculated using the equation: OM ingested (g/day) - [duodenal OM (g/day) - microbial OM(g/day)].

After the period of collection, samples of feed, orts, feces and omasal digestive content were dried at $55^{\circ} \mathrm{C}$ for 72 hours, individually milled $(1 \mathrm{~mm})$ and mixed in equal parts, so the dry weight was estimated to compose samples of feces and animal digestive tract content for each animal and each experimental diet.

Contents of dry matter (DM), organic matter (OM), crude protein (CP) and ether extracts (EE) were determined following Silva \& Queiroz (2002). Evaluation of neutral detergent fiber (NDF) and acid detergent fiber (ADF) was conducted according to Van Soest et al. (1991). Chemical analysis of NDF and ADF residues, neutral detergent insoluble nitrogen (NDIN) and acid detergent insoluble nitrogen (ADIN) were done according to Licitra et al. (1996). Lignin concentration was estimated by potassium permanganate oxidation methodology according to Van Soest \& Wine (1998) and concentration of silica was done following Van Soest \& Jones (1968). Total carbohydrates (TC) were quantified by the equation: $100-(\% \mathrm{CP}+\% \mathrm{EE}+$ $\%$ ash) and non-fibrous carbohydrates (NFC) content was determined by the difference between the content of TC and $\mathrm{NDF}_{\mathrm{P}}$, where $\mathrm{NDF}_{\mathrm{P}}$ stands for the NDF without CP from the cell wall (Sniffen et al., 1992).

Ammonia dosage from rumen samples was determined by the Ferner (1965) technique modified by Vieira (1980).

For the determination of short chain fatty acids concentration, samples were centrifuged at $14.000 \times \mathrm{g}\left(4^{\circ} \mathrm{C}\right)$ for 40 minutes, according to Palmiquist \& Conrad (1971) in liquid-gas chromatography machine (Hewlett Packard 5890 Series II GC) equipped with integrator (Hewlett Packard 3396 Series II Integrator) and automatic injector (Hewlett Packard 6890 Series Injector). The internal pattern was 2-Methylbutyric acid, with addition of $100 \mu \mathrm{L}$ in each tube, $800 \mu \mathrm{L}$ of the sample and $200 \mu \mathrm{L}$ of $85 \%$ formic acid. A mix of short-chain fatty acids with known concentration was used to calibrate the integrator.

Rumen dilution rate was estimated by the diminishing concentration of ruminal cobalt over time. Rumen liquid samples were unfrozen and centrifuged at $2296 \mathrm{x}$ g for 30 minutes and the reading of the supernatant was done through spectrophotometer with atomic absorption determining the Co concentration of the supernatant.

Liquid passage rate and cobalt $(\mathrm{Co})$ rumen concentration curves were adjusted to the uni-compartmental exponential model by Hungate (1966), cited by Colucci (1984): $\mathrm{Y}_{\mathrm{Co}}=\mathrm{A}$ $\times \mathrm{e}^{(-\mathrm{K} 1 . \mathrm{t})}$, where $\mathrm{Y}_{\mathrm{Co}}=$ indicator of concentration in time $\mathrm{t}$; $\mathrm{A}=$ concentration of Co balance in $\mathrm{t}=0$ considering instant dilution; $\mathrm{K}_{1}=$ Co dilution or passage rate; and $\mathrm{t}=$ sampling time. Dynamics parameters of the liquid phase were calculated according to Colucci et al. (1990): Rumen retention time $(\mathrm{h})(\mathrm{TeR})=1 /$ fluid passage rate $(\% \mathrm{~h})\left(\mathrm{k}_{1 \mathrm{Co}}\right)$; Rumen liquid volume $(\mathrm{L})(\mathrm{VLR})=$ amount of Co supplied $(\mathrm{mg}) / \mathrm{A}$; Rumen flow rate $(\mathrm{L} / \mathrm{h})(\mathrm{T} \times \mathrm{F})=\mathrm{k}_{1 \mathrm{Co}} \times \mathrm{VLR}$ and recycling rate (RR) of liquid phase were calculated following Maeng \& Baldwin (1976): RR ( ${ }^{\circ}$ times/day) $=24 \mathrm{~h} / \mathrm{TeR}$.

The experimental design was two $4 \times 4$ Latin squares with $4 \times 2$ factorial arrangement (four diets and two species): one species with Latin Square to measure and compare intake and nutrients digestible coefficient, liquid 
phase dynamics and microbial efficiency synthesis. Variables of statistical analysis were interpreted by the SAEG (Sistema de Análises Estatísticas e Genéticas, versão 7.1). Means were compared by the Tukey test with 0.05 significance. The rumen liquid values of $\mathrm{pH}, \mathrm{N}-\mathrm{NH}_{3}$ and short-chain fatty acids observed were subdivided in portions based on time per sample. Regression analysis was utilized to estimate rumen concentration values of $\mathrm{pH}$, $\mathrm{N}-\mathrm{NH}_{3}$ and short-chain fatty acids. All the extents values were determined based on the time after morning feeding $(0,2,4,6$, and 8$)$ for each treatment.

\section{Results and Discussion}

The sugar cane silage with additive showed significant difference $(\mathrm{P}<0.05)$ for DM intake. Overall, feed intake was low (bovine intake, 16.5, and buffaloes intake, $14.6 \mathrm{~g} / \mathrm{kg}$ BW). The sugar cane silage with addition of urea decreased the intake of DM, OM, NDF and total carbohydrates in both species (Table 2).

Due to the indigestible fiber portion, fiber digestibility and potential degradability low rates $(0.034 / 1 \mathrm{~h})$, which increase rumen feed time, sugar cane DM intake usually show negative results (Pereira et al., 2000). Corroborating with this data, fraction $b$ of NDF degradable rate in additives sugar cane silage used in this experiment showed value of 0.0222/h (Maeda et al., 2011), digestible rate 1.5 times lower than the previous experiment above-mentioned. It is likely that the precocious variety of sugar cane used in this experiment contributed to a low intake and low digestible rate. Azevedo et al. (2003) affirmed that sugar cane varieties with intermediate cycles are qualitative superior, because they have higher values of total digestibility N, attributed to low ADF concentration (Fernandes et al., 2003). Thus, precocious varieties reach maturity early and present higher development rate of structural tissue.

The silage with inoculate + urea diet showed the lowest intake (33 g/kg urea DM), and the lowest acceptability among the diets; these results can be attributed to alcoholic content and ammoniacal odor. Data corroborate with Vilela et al. (2003), who observed low intake for crossbred Holstein $\times$ Gir fed sugar cane diet with addition of $35 \mathrm{~g} / \mathrm{kg}$ urea. The diets with inoculate and with inoculate + soybean hulls showed $(\mathrm{P}<0.05)$ higher $\mathrm{CP}$ and total digestibility nutrients intake; diets with inoculate + cassava byproduct showed intermediate values regardless of the species. The diet with addition of soybean hulls $(\mathrm{P}<0.05)$ showed the highest NDF intake, which include higher fiber digestibility, thus increasing the passage rate and feed intake.

The DM intake for bovines $(8.11 \mathrm{~kg} /$ day $)$ was higher $(\mathrm{P}<0.05)$ than for bubaline $(5.84 \mathrm{~kg} /$ day $)$. However, expressed in $\mathrm{g} / \mathrm{kg}$, body weight $(\mathrm{BW})$ did not show differences $(\mathrm{P}>0.05)$ between species. DM and nutrients intake are below the desirable value to achieve specific and higher levels of productivity.

Buffaloes DM intake was inferior to the values recommend by Kearl (2003), of $7.0 \mathrm{~kg}$ DM/day for buffaloes maintenance. $\mathrm{CP}$ intake and total digestibilityN were above buffaloes maintenance requirements of $0.469 \mathrm{~kg} \mathrm{CP} /$ day and $3.37 \mathrm{~kg}$ total digestibility N/day. However, bovine DM intake was above recommended by the NRC (1996): $7.3 \mathrm{~kg}$ DM for animals with $550 \mathrm{~kg} \mathrm{BW}$ fed diets $600 \mathrm{~g} / \mathrm{kg}$ total digestibilityN, during 84 days of trial daily gain of animals was $230 \mathrm{~g} /$ day.

Table 2 - Means and coefficients variation (CV) of DM intake and nutrients from experimental diets on both species

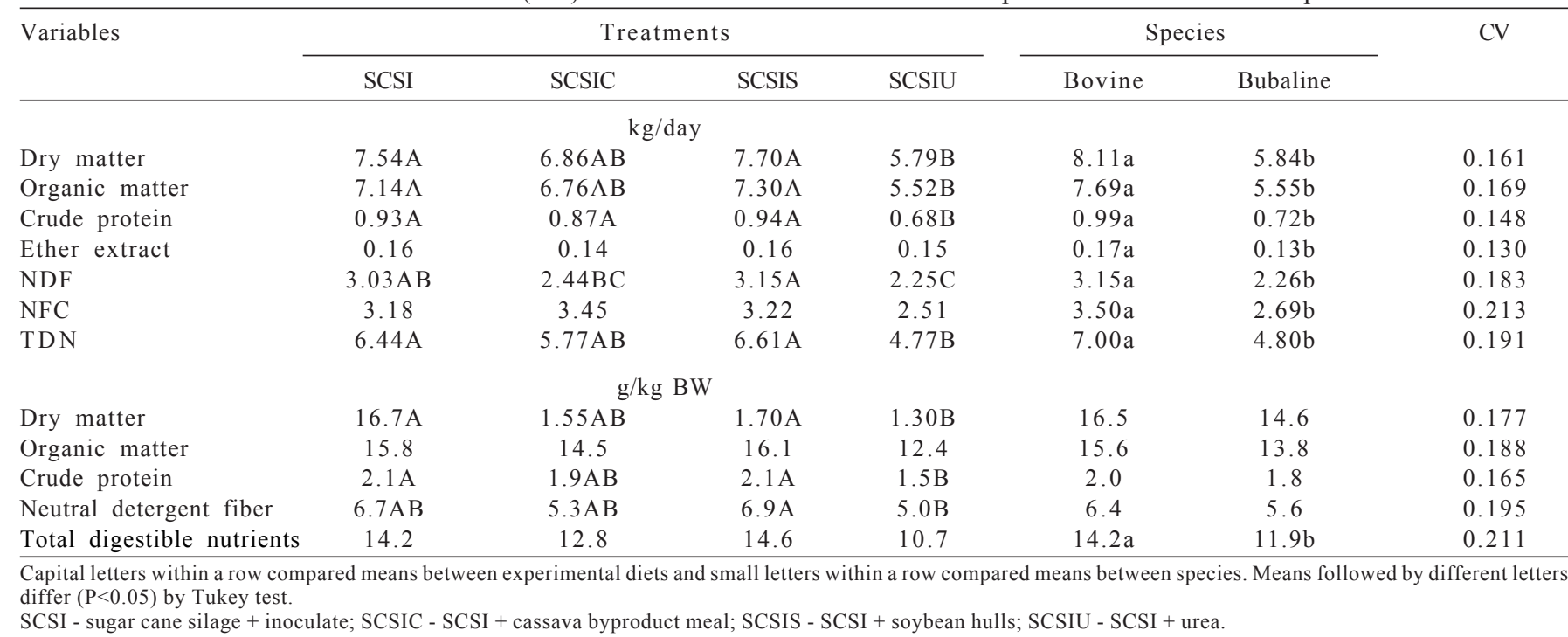


There was effect of the diet $\times$ species interaction of total digestibility (total digestibility) of CP and neutral detergent fiber (NDF) values (Table 3). Only the diet with soybean hulls presented total digestibility of CP higher in bovine. However, regardless of the species, soybean hulls addition increased total digestibility of NDF $(\mathrm{P}<0.05)$ in the diets. The superiority of the diet with inoculate + soybean hulls is due the nutritional characteristics of soybean hulls, which showed high content of NDF (70.46\%) and ADF (55.41\%), high in vitro digestibility, superior to $90 \%$ (Zambom et al., 2001). Also, soybean hulls are rich in pectin (cell wall carbohydrate), which is completely fermented in the rumen (Van Soest, 1994). Importantly, the addition of soybean hulls represented $250 \mathrm{~g} / \mathrm{kg}$ of forage when expressed in DM.

Only the diet with urea showed difference for total digestibility of NDF $(\mathrm{P}<0.05)$ between species, with higher digestibility values observed in buffaloes. Data corroborate with Pradhan et al. (1997) and Kawashima (2004), for differences in fiber digestibility between bovine and bubaline fed low-quality diets. The diet with urea had the lowest quality among the diets, due to high levels of lignin $(89.0 \mathrm{~g} / \mathrm{kg})$ and silica $(32.5 \mathrm{~g} / \mathrm{kg})$ content. In this way lignin, silica and other compounds (cutin and tannins), which are components of the cell wall, associated or not with structural polysaccharides and/or lignin, even in small amounts, can cause a negative effect on the digestion and absorption process of nutrients (Van Soest, 1994).

Effect of rumen digestibility on DM, OM, NDF, ADF and NFC was observed for the species $\times$ diet interaction (Table 3). Only bovine showed differences for rumen digestibility of DM, OM and NDF among diets, and superior values for the diet with urea. The results of this diet can be associated with the high concentration of soluble nitrogen and low concentrations of insoluble nitrogen in neutral and acid detergent (Table 2). High quantity of soluble nitrogen may have favored rumen cellulolytic microorganism growth, which increment fiber fermentation, and rumen digestibility of DM, OM and NDF. There was no interference of rumen fermentation activities on total digestibility of DM and $\mathrm{OM}$ results of the diet with addition of urea (Table 4).

Inverse nutritional behavior was observed in buffaloes that obtained low rumen protein digestibility coefficient. There was higher ammoniacal nitrogen recycling in bubaline than bovine; this result could be masked by higher or lower dietetic $\mathrm{N}$ effects in the ruminal digestibility of DM, OM and NDF. Than \& Ørskov (2006) observed the lowest purine derivate excretion in buffaloes compared with bovine $\left(0.26 \mathrm{vs} 0.69 \mathrm{mmol} / \mathrm{kg} \mathrm{BW}^{0.75}\right)$, which suggests low value of glomerular filtration rate or higher blood permeability to the rumen, which leads to higher nitrogen recycling for microbial metabolism.

Different behavior for non-fibrous carbohydrates rumen digestibility ( $\%$ ingested) between bovine and buffaloes were observed; this result is probable associated with a microbial difference between species (Franzolin et al., 2002). For bovine, there was no difference observed for nonfibrous carbohydrate ruminal digestibility; however, in buffaloes, there were high values of ruminal digestibility for the diet with inoculate only and the diet with inoculate + cassava byproduct than the diet with inoculate + urea.

There was no interaction of diet and species $(\mathrm{P}>0.05)$ for total digestibility of $\mathrm{DM}, \mathrm{OM}$ and non-fibrous carbohydrates (Table 4). However, there was diet effect

Table 3 - Means and coefficient variation (CV) of total and partial apparently coefficient of digestibility with interaction between experimental diets and species

\begin{tabular}{|c|c|c|c|c|c|c|c|c|c|}
\hline \multirow{3}{*}{ Nutrients } & \multicolumn{8}{|c|}{ Treatments } & \multirow[b]{3}{*}{$\mathrm{CV}$} \\
\hline & \multicolumn{4}{|c|}{ Bovine } & \multicolumn{4}{|c|}{ Bubaline } & \\
\hline & SCSI & SCSIC & SCSIS & SCSIU & SCSI & SCSIC & SCSIS & SCSIU & \\
\hline Crude protein & $0.583 \mathrm{Aa}$ & $0.513 \mathrm{Ba}$ & $0.610 \mathrm{Aa}$ & $0.504 \mathrm{Ba}$ & $0.576 \mathrm{Aa}$ & $0.485 \mathrm{Ba}$ & $0.493 \mathrm{Bb}$ & $0.492 \mathrm{Ba}$ & 0.126 \\
\hline $\mathrm{NDF}$ & $0.351 \mathrm{Ba}$ & $0.232 \mathrm{Ca}$ & $0.446 \mathrm{Aa}$ & $0.195 \mathrm{Cb}$ & $0.283 \mathrm{Ba}$ & $0.218 \mathrm{Ba}$ & $0.457 \mathrm{Aa}$ & $0.284 \mathrm{Ba}$ & 0.341 \\
\hline Organic matter ${ }^{2}$ & $0.676 \mathrm{ABa}$ & $0.602 \mathrm{BCa}$ & $0.563 \mathrm{Ca}$ & $0.740 \mathrm{Aa}$ & $0.554 \mathrm{~b}$ & $0.517 \mathrm{~b}$ & $0.491 \mathrm{~b}$ & $0.499 \mathrm{~b}$ & 0.113 \\
\hline $\mathrm{NDF}^{2}$ & $0.933 \mathrm{~B}$ & $0.951 \mathrm{AB}$ & $0.912 \mathrm{~B}$ & $1.06 \mathrm{~A}$ & 1.04 & 0.963 & 0.955 & 0.932 & 0.068 \\
\hline $\mathrm{NFC}^{1}$ & $0.647 \mathrm{a}$ & $0.599 \mathrm{a}$ & $0.609 a$ & $0.684 a$ & $0.541 \mathrm{Ab}$ & $0.612 \mathrm{Aa}$ & $0.527 \mathrm{ABb}$ & $0.435 \mathrm{Bb}$ & 0.077 \\
\hline $\mathrm{NFC}^{2}$ & $0.745 \mathrm{ABa}$ & $0.675 \mathrm{Ba}$ & $0.667 \mathrm{Ba}$ & $0.820 \mathrm{Aa}$ & $0.607 \mathrm{ABb}$ & $0.679 \mathrm{Aa}$ & $0.610 \mathrm{ABa}$ & $0.528 \mathrm{Bb}$ & 0.102 \\
\hline
\end{tabular}

Capital letters compared means within a row between experimental diets and small letters compared means within a row between species in experimental diets. Means followed by different letters differ $(\mathrm{P}<0.05)$ by Tukey test.

$1 \%$ arrives in compartment.

$2 \%$ total digested.

SCSI - sugar cane silage + inoculate; SCSIC - SCSI + cassava byproduct meal; SCSIS - SCSI + soybean hulls; SCSIU - SCSI + urea

$\mathrm{NDF}$ - neutral detergent fiber; NFC - non-fibrous carbohydrates. 
Table 4 - Means and coefficient variation (CV) of total apparent and partial coefficient of digestibility and levels of total digestible N of experimental diets and species $(\mathrm{g} / \mathrm{kg} \mathrm{DM})$

\begin{tabular}{|c|c|c|c|c|c|c|c|}
\hline \multirow[t]{2}{*}{ Components } & \multicolumn{4}{|c|}{ Treatments } & \multicolumn{2}{|c|}{ Species } & \multirow[t]{2}{*}{$\mathrm{CV}$} \\
\hline & SCSI & SCSIC & SCSIS & SCSIU & Bovine & Bubaline & \\
\hline \multicolumn{8}{|c|}{ Total digestibility } \\
\hline Organic matter & $0.590 \mathrm{~B}$ & $0.584 \mathrm{~B}$ & $0.639 \mathrm{~A}$ & $0.532 \mathrm{C}$ & 0.584 & 0.588 & 0.060 \\
\hline Ether extract & 0.709 & 0.668 & 0.696 & 0.717 & 0.702 & 0.693 & 0.069 \\
\hline Non-fibrous carbohydrates & $0.879 \mathrm{~A}$ & $0.898 \mathrm{~A}$ & $0.889 \mathrm{~A}$ & $0.829 \mathrm{~B}$ & 0.876 & 0.872 & 0.038 \\
\hline Crude protein ${ }^{1}$ & -0.06 & -0.09 & -0.11 & -0.09 & -0.04 & -0.11 & 0.938 \\
\hline Crude protein ${ }^{2}$ & -0.01 & -0.19 & -0.20 & -0.18 & $-0.08 \mathrm{a}$ & $-0.210 b$ & 0.112 \\
\hline Total carbohydrates & 0.731 & 0.705 & 0.658 & 0.715 & $0.748 \mathrm{a}$ & $0.657 \mathrm{~b}$ & 0.095 \\
\hline
\end{tabular}

$(\mathrm{P}<0.05)$ with high values of total digestibility for the diet with soybean hulls and lower values of total digestibility for the diet with urea. The same pattern was observed for total digestible nutrients with high values for the diet with soybean hulls and lower values for the diet with addition of urea.

Soybean hulls and cassava byproduct meal addition in the sugar cane silages increased the values of DM compared with the control diet, making silos less favorable to undesirable microorganism proliferation. Furthermore, soybean hulls have a high nutritional value, which increases the digestibility coefficient. However, the diet with urea showed less acceptability by the animal, with low nutritional quality. There was a reduction of $27 \%$ aerobic stability when urea was added in sugar cane mini-silo, compared with the control diet in a concomitant experiment. The alcoholic odor observed from silage inoculate + urea diet in this experiment is due to low aerobic stability.

Difference was observed $(\mathrm{P}<0.05)$ in ruminal digestibility for $\mathrm{CP}$ and total carbohydrates (\% total intake) with high values for bovines and low values for buffaloes (Table 4). The lowest negative values for ruminal digestibility of $\mathrm{CP}$ in buffaloes are indicative that the amount of $\mathrm{N}$ that reaches the duodenum is greater than the $\mathrm{N}$ intake; this event reflects in greater endogenous $\mathrm{N}$ recycling in the rumen and higher microbial protein synthesis in buffaloes compared with bovines (Table 5).

Bovines showed greater $(\mathrm{P}<0.05)$ ruminal digestibility of total carbohydrates ( $\%$ total digested). There was no difference observed in ruminal digestibility of NDF between species, and greater rumen digestibility of NFC was observed in bovines due to greater ruminal digestibility of TC.

There were no species $\times$ diets interaction, species $\times$ sampling time or diets $\times$ sampling time $(\mathrm{P}>0.05)$ for rumen liquid pH (Figure 1); however, without interaction between

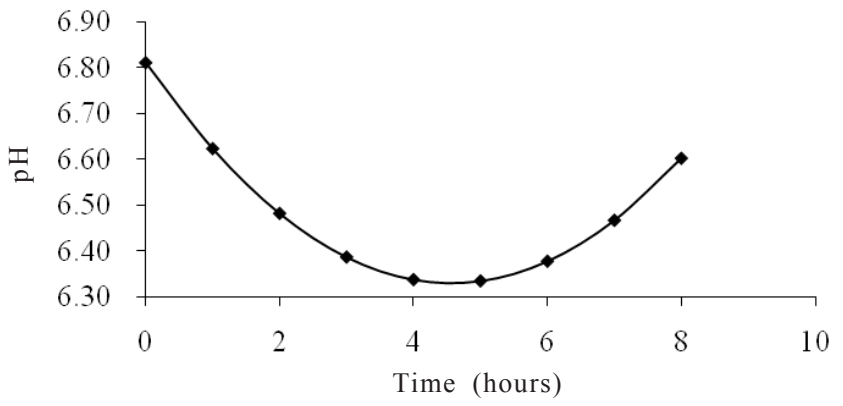

Figure 1 - Ruminal liquid $\mathrm{pH}$ in relation of time after feeding sugar cane silage with different additives.

them, there were differences for diets, species and sampling time $(\mathrm{P}<0.05)$. A square effect in function of time after feeding was observed with the following equation: $\hat{\mathrm{Y}} \mathrm{pH}=$ $6.81-0.21 \mathrm{~T}+0.023 \mathrm{~T}^{2}\left(\mathrm{R}^{2}=0.97\right)$, where $\mathrm{T}=$ time after feeding. The minimum rumen liquid $\mathrm{pH}$ concentration was 6.33 at 4:56 hours. The lowest NDF intake observed (average lower than $6 \mathrm{~g} / \mathrm{kg} \mathrm{BW}$ ) seems not to interfere on salivary flux or rumination process.

Ruminal liquid $\mathrm{pH}$ values showed differences between diets with average of $6.48,6.48,6.60$ and 6.64 for the diets with cassava, urea, and inoculate only, respectively. However, none of the $\mathrm{pH}$ values has caused interference on cellulolytic microorganisms which are sensitive to $\mathrm{pH} 6.2$ or lower.

Higher average values of ruminal liquid $\mathrm{pH}(\mathrm{P}<0.05)$ were observed in buffaloes (6.61), compared with bovines (6.48). This data corroborates the literature (Souza et al., 2000; Beleze, 2005; Maeda et al., 2007). According to Sivkova et al. (1997), buffaloes present more intense salivary secretion and greater tamponate effect in the rumen.

The concentration of rumen ammoniacal $\mathrm{N}\left(\mathrm{N}-\mathrm{NH}_{3}\right)$ showed cubic effect in the interaction of sampling time and diet. There was no effect regarding the interaction of species 
$\times$ diet, also there was no effect in either species for $\mathrm{N}-\mathrm{NH}_{3}$ concentrations (Figure 2).

Regression equations were adjusted for the $\mathrm{N}-\mathrm{NH}_{3}$ concentration in ruminal liquid $(\mathrm{mg} / 100 \mathrm{~mL})$ within relation of sampling time for each diet, regardless of the species, with the following values: $\mathrm{NH}_{3}=7.56+5.46 \mathrm{X}-1.60 \mathrm{X}^{2}+$ $0.11 \mathrm{X}^{3}$ (control diet); $\mathrm{NH}_{3}=7.65+3.94 \mathrm{X}-1.13 \mathrm{X}^{2}+0.08 \mathrm{X}^{3}$ (diet with cassava byproduct) $\mathrm{NH}_{3}=7.96+5.83 \mathrm{X}-1.78 \mathrm{X}^{2}$ $+0.13 \mathrm{X}^{3}$ (diet with soybean hulls); $\mathrm{NH}_{3}=5.82+11.41 \mathrm{X}-$ $3.35 \mathrm{X}^{2}+0.24 \mathrm{X}^{3}$ (diet with urea).

Diets with low and high levels of ruminal liquid $\mathrm{N}-\mathrm{NH}_{3}$ were those with the addition of cassava byproduct and urea. Furthermore, the maximum concentration of $\mathrm{N}-\mathrm{NH}_{3}$ in the diet with cassava was $11.71 \mathrm{mg} / 100 \mathrm{~mL}$, and the lowest was $7.51 \mathrm{mg} / 100 \mathrm{~mL}$, around 2:00 and 7:00 hours after feeding. For the diet with urea, at the same times, the high ruminal concentration of $\mathrm{N}-\mathrm{NH}_{3}$ was $17.25 \mathrm{mg} / 100 \mathrm{~mL}$ and the lowest was $3.2 \mathrm{mg} / 100 \mathrm{~mL}$. Therefore, the diet with urea with the biggest amount of available ammonia for the rumen microorganisms showed results with values lower than the minimum limits in the periods preceding the evening feeding. The diet with inclusion of cassava byproduct showed rumen ammonia concentrations above the minimum values recommended $(5 \mathrm{mg} / 100 \mathrm{~mL}$ ruminal liquid) by Satter \& Roffler (1975)to prevent inhibition of rumen microbial growth. However, the highest values observed were below the interval of 19 to $23 \mathrm{mg} \mathrm{N}-\mathrm{NH}_{3} / 100 \mathrm{~mL}$ for maximum rumen fermentation activity set by Mehrez \& Ørskov (1977).

Concentrations of short-chain fatty acids in ruminal liquid showed no interaction between species $\times$ diet, species $\times$ sampling time, diet $\times$ sampling time $(\mathrm{P}>0.05)$ or effect on species. However, there was difference between diets and square effect for time after feeding $(\mathrm{P}<0.05)$ (Figure 3$)$.
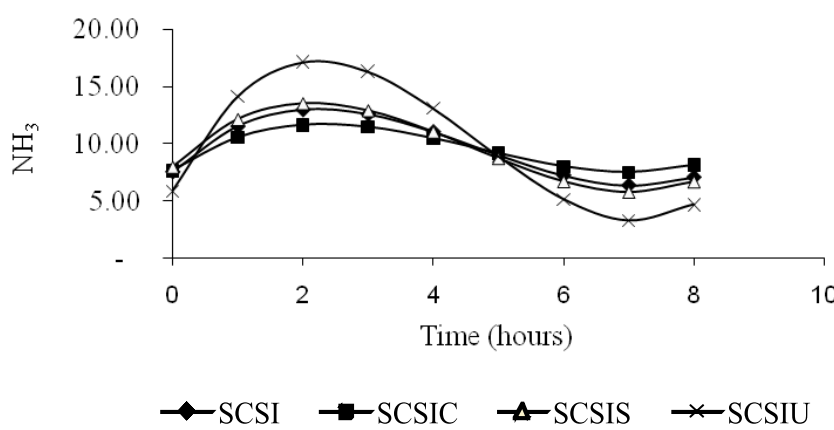

SCSI - sugar cane silage + inoculates; SCSIC - SCSI + cassava by product meal; SCSIS - SCSI + soybean hulls; SCSIU - SCSI + urea.

Figure 2 - N ammoniacal concentration of ruminal liquid $\left(\mathrm{N}-\mathrm{NH}_{3}\right)$ $\mathrm{mg} / 100 \mathrm{~mL}$ within relation of time after feeding for experimental diets.
Rumen fatty acids are produced especially from the carbohydrates fermentation, such as cellulose, hemicellulose, pectin and sugars. Although the diet contained similar amounts of total carbohydrates, sugar cane silage with soybean hulls and cassava byproduct meal showed higher total molarity concentration of short-chain fatty acids compared with the diet with inoculate only $(60.5 \mu \mathrm{M} / \mathrm{mL} ; 61.24 \mu \mathrm{M} / \mathrm{mL}$ and $46.7 \mu \mathrm{M} / \mathrm{mL}$, respectively). The diet with cassava byproduct meal showed high concentration of NFC $(\mathrm{g} / \mathrm{kg}$ DM), which can contribute to high production of shortchain fatty acids. The diet with addition of soybean hulls showed the highest values, which can be related to the higher digestibility of total fiber portion $(\mathrm{P}<0.05)$ observed in both species.

Animals fed the diet with urea showed rumen concentrations of acetate, propionate and butyrate similar to the diet with only addition of inoculate, with an exception of isobutyrate levels, which showed lower concentration in the diet with urea.
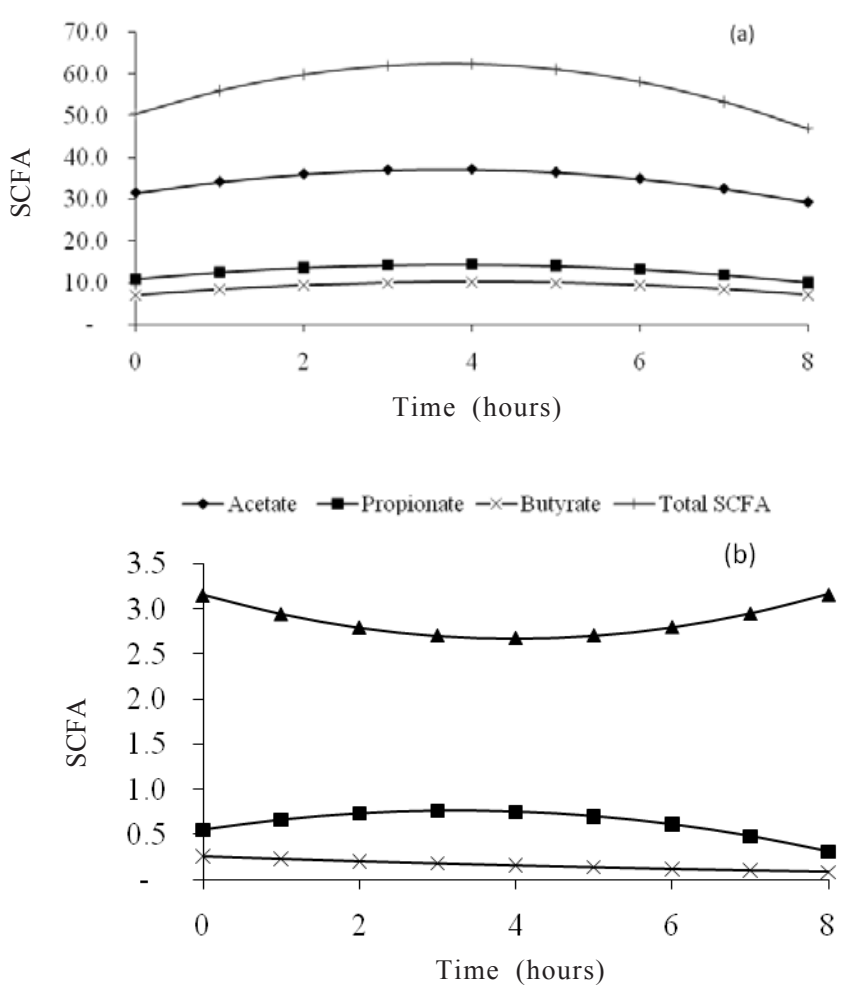

$\leftarrow$ Isobutyrate $\rightarrow$-Valerate $\multimap$ Acetate:Propionate

Figure 3 - Concentrations of acetate, butyrate propionate and total short-chain fatty acids (SCFA) (a), isobutyrate, valerate and ratio acetate:propionate (b) $\mu \mathrm{M} / \mathrm{mL}$ of ruminal liquid in relation to time after feeding, regardless of the species (bovine and bubaline). 
There was no difference observed $(\mathrm{P}>0.05)$ in buffaloes and bovines for short-chain fatty acids concentration. Previous studies showed similar results with little or no difference in short-chain fatty acids concentration between species fed different diets (Ranjhan et al., 1993; Souza, et al., 2000; Zeoula et al., 2006).

There was no effect observed for interaction between species and diet nor of diet on liquid passage rate (rate \%/ hour), recycle time (hours), recycle rate (times/day) or liquid flow rate (litters/hour); however, there were different results between species (Table 5).

Usually, rumen liquid passage rate increase in proportion with forage percentage in the diet and feed intake (Valadares Fillho \& Pina, 2006). There was no difference for rumen liquid passage rate $(\% \mathrm{~h})$ between diets; however, NDF results were close to the average values of $416.0 \pm 29 \mathrm{~g} / \mathrm{kg}$.

Higher liquid passage rate was observed in buffaloes; therefore, higher ruminal liquid retention time was observed in bovines, due to the inverse effect between these variables. Singh et al. (1992) suggested a low ruminal retention time in buffaloes due to a slow mastication, but more efficiency on fiber portions degradation.

Diets caused an average recycle rate of 2.68 times/day, similar values reported by Prado et al. (2010) of 2.7 times/day in bovine and buffaloes fed with corn silage, Tifton 85 with addition of propolis and monensin sodium.

Average ruminal volume in buffaloes was 66.0 litters and, in bovines, it was 59.9 litters, which represents 165 and $122 \mathrm{~g} / \mathrm{kg} \mathrm{BW}$, respectively. Bartocci et al. (1997) observed similar results in buffaloes with $417.1 \mathrm{~kg} \mathrm{BW}$ and 65.8 litters average $(\mathrm{P}<0.05)$ of ruminal volume and bovines with $509.2 \mathrm{~kg}$ BW with 59.1 litters with different forage:concentrate ratios in the diets. Franzolin et al. (2002) observed that buffaloes increased the ruminal volume on diets with high levels of NDF compared with low levels of NDF (90.30 vs 62.05); however, in bovines there was no effect due to different levels of NDF in the diet showing ruminal volume average values of 84.32 litters.
There was no effect due to interaction $(\mathrm{P}>0.05)$ species and diet for $\mathrm{OM}$ and $\mathrm{N}$ intake; however, there was a diet effect $(\mathrm{P}<0.05)$ on nitrogen flow and rumen degradable $\mathrm{OM}$ (Table 6). The diet with urea showed the lowest $\mathrm{N}$ rates and rumen apparently degrade $\mathrm{OM}$, and the diet with soybean hulls diet showed the highest $\mathrm{N}$ rates for the omasum, the microbial N (N-mic) and non-microbial N (NN-mic) (g/day), experimental diets showed no differences for $\mathrm{N}$ rates in the omasum. In the same pattern, there was no difference between diets $(\mathrm{P}>0.05)$ for microbial protein production (Pmic, g protein/100g rumen apparent degradable organic matter) and EFmic ( $\mathrm{g} \mathrm{N}$-mic/kg rumen apparent degradable organic matter and $\mathrm{g} \mathrm{N}-\mathrm{mic} / \mathrm{kg}$ rumen total digestibility of organic matter).

There was a species effect $(\mathrm{P}<0.05)$ on the result of omasal $\mathrm{N}$ rates, $\mathrm{NN}$-mic and rumen true degradable organic matter (g/day) and for rumen apparently degradable organic matter (intake $\%$ and $g /$ day); bovines showed higher values than buffaloes. Even in the results cited above, buffaloes showed higher microbial protein synthesis and efficiency of microbial protein synthesis $(\mathrm{P}<0.05)$, compared with bovines. This data corroborates with negative values of protein rumen digestibility, which showed higher rates of duodenum $\mathrm{N}$ in relation with the $\mathrm{N}$ intake, double than the observed with bovine.

Bovine microbial synthesis efficiency was similar to the ARC (1984) recommendation of $32.0 \mathrm{~g} \mathrm{~N}-\mathrm{mic} / \mathrm{kg}$ rumen apparent degradable organic matter in mix diet, and buffaloes showed higher values. The highest value of efficiency of microbial synthesis observed in buffaloes can be attributed to the fast liquid passage rate. Russell (1998), cited by Arcuri et al. (2006), explains that with the rise of dilution rate, the perceptual energy derivate from cell substrate increases, while short-chain fatty acids are excreted or dissipate as heat (maintenance energy) is reduced. This way, the renovation rate of ruminal microbial population expresses high efficiency of microbial protein synthesis in buffaloes.

Table 5 - Liquid passage rate (LPR, \%/hour), retention time (RT, hours), recycling rate (RR, times/day), liquid flow rate (FR, litters/hour) and ruminal volume (RV) in sugar cane silage with different additives for bovine and bubaline

\begin{tabular}{|c|c|c|c|c|c|c|c|}
\hline \multirow[t]{2}{*}{ Variables } & \multicolumn{4}{|c|}{ Treatments } & \multicolumn{2}{|c|}{ Species } & \multirow[t]{2}{*}{$\mathrm{CV}$} \\
\hline & SCSI & SCSIC & SCSIS & SCSIU & Bovine & Bubaline & \\
\hline LPR, \%/hours & 11.4 & 11.1 & 11.8 & 9.9 & $9.9 \mathrm{~b}$ & $12.2 \mathrm{a}$ & 0.196 \\
\hline RT, hours & 8.7 & 9.8 & 8.9 & 10.6 & $10.4 \mathrm{a}$ & $8.6 \mathrm{~b}$ & 0.522 \\
\hline RR, times/day & 2.8 & 2.7 & 2.8 & 2.4 & 2.5 & 2.8 & 0.285 \\
\hline FR (L/h) & 8.3 & 7.8 & 8.6 & 6.5 & 7.2 & 8.4 & 0.368 \\
\hline $\mathrm{RV}(\mathrm{L})$ & 56.4 & 67.0 & 65.3 & 63.3 & 59.9 & 66.0 & - \\
\hline RV (g/kg BW) & 130.0 & 152.0 & 149.0 & 144.0 & 122.0 & 165.0 & - \\
\hline
\end{tabular}

SCSI - sugar cane silage + inoculate; SCSIC - SCSI + cassava byproduct meal; SCSIS - SCSI + soybean hulls; SCSIU - SCSI + urea; CV - coefficient variation.

Means followed by different letters $\operatorname{differ}(\mathrm{P}<0.05)$ by Tukey test. 
Table 6 - Organic matter ingested (OMI) and nitrogen intake (NI), microbial N rate (N-mic), omasum non-microbial N(NN-mic), rumen apparent degradable organic matter (RADOM), and rumen true degradable organic matter (RTDOM), ruminal apparently and truly organic matter digestion, microbial production (PMic) and apparently and true efficiency of microbial synthesis

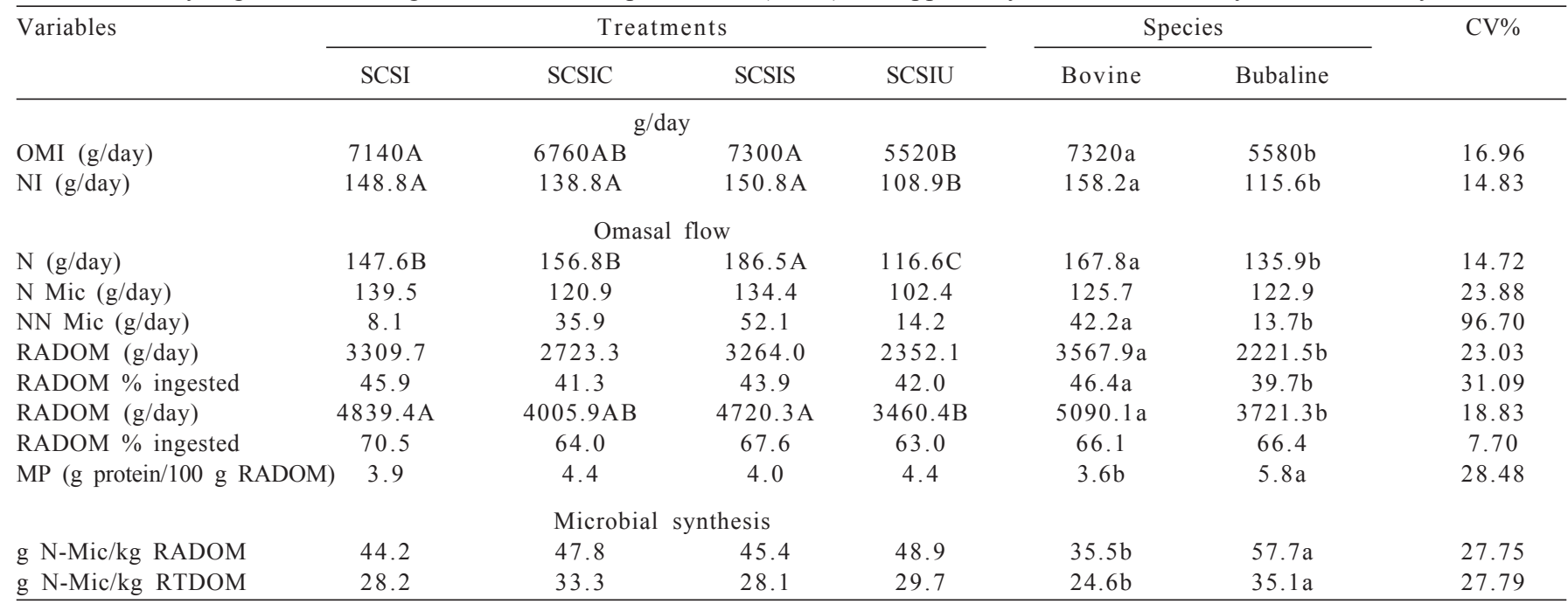

SCSI - sugar cane silage + inoculate; SCSIC - SCSI + cassava byproduct meal; SCSIS - SCSI + soybean hulls; SCSIU - SCSI + urea; CV - coefficient variation. Means followed by different letters differ $(\mathrm{P}<0.05)$ by Tukey test.

Microbial protein synthesis in buffaloes was observed to be higher in diets with low protein content, and low efficiency of synthesis if animals were fed high proteincontent diets (Kewalramani \& Gupta, 1987). Kurar \& Mudgal (1981) observed high microbial activity and efficient N recycle in buffaloes, reason why the requirement of protein in buffaloes is lower if compared with bovine.

\section{Conclusions}

Sugar cane silage with addition of Lactobacillus buchneri and soybean hulls provides forage with better quality. Association of urea and Lactobacillus buchneri in the sugar cane silage increases rumen fermentation in bovines; however, it does not improve digestive tract nutrients absorption or compromise feed intake. Bubaline fed sugar cane silage and urea shows more efficiency on fiber digestibility than bovine. Bubaline and bovine fed sugar cane silage inoculated with Lactobacillus buchneri and soybean hulls or cassava byproduct meal shows different results, with higher values of microbial protein synthesis efficiency in bubaline.

\section{References}

AGRICULTURAL RESEARCH COUNCIL - ARC. 1984. Report of the protein group of the Agricultural Research Council Working party, on the nutrient requirement of ruminants. London: Commonwealth Agricultural Bureaux. $45 \mathrm{p}$.

ANUAlPeC. Anuário da Pecuária Brasileira. São Paulo: Instituto FNP, 2006. 369p.
ARCURI, P.B.; LOPES, F.C.F.; CARNEIRO, J.C. Microbiologia do rúmen. In: BERCHIELLI, T.T.; PIRES, A.V.; OLIVEIRA, S.G. (Org.). Nutrição de ruminantes. 1.ed. Jaboticabal: Funep, 2006. p. 111-150.

AZEVEDO, J.A.G.; PEREIRA, J.C.; QUEIROZ, A.C. Composição químico-bromatológica, fracionamento de carboidratos e cinética da degradação in vitro da fibra de três variedades de cana-de-açúcar (saccharum spp.). Revista Brasileira de Zootecnia. v.32, n.6, p.1443-1453, 2003.

BARTOCCI, S.; AMICI, A.; VERNA, M. et al. Solid and fluid passage rate in buffalo, cattle, and sheep fed diets with different forage to concentrate ratios. Livestock Production Science, v.52, n.3, p.201-208, 1997.

CECAVA, M.J.; MERCHEN, N.R.; GAY, L.C.E. et al. Composition of ruminal bacteria harvested from steers as influenced by dietary energy level, feed frequency, and isolation techniques. Journal of Dairy Science, v.73, n.12, p.2480-2490, 1990.

COLUCCI, P.E. Comparative digestion and digesta kinetics in sheep and cattle. 1984. 221f. Thesis (Ph.D. in Animal Science) - University of Guelph, Guelph.

COLUCCI, P.E.; MACLEOD, G.K.; GROVUM, W.L. et al. Digesta kinetics in sheep and cattle fed diets with different forage to concentrate ratios at high and low intakes. Journal of Dairy Science, v.73, p.2143-2156, 1990.

FERNANDES, A.M.; QUEIROZ, A.C.; PEREIRA, J.C. et al. Composição químico-bromatológica de variedades de cana-deaçúcar (Saccharum spp L.) com diferentes ciclos de produção (precoce e intermediário) em três idades de corte. Revista Brasileira de Zootecnia, v.32, n.4, p.977-985, 2003

FRANZOLIN, M.H.T.; SILVEIRA, A.C.; FRANZOLIN, R. Efeitos de dietas com diferentes níveis de fibra em detergente neutro e do tamanho de poros de sacos de náilon incubados no rúmen sobre a fauna ruminal em bubalinos e bovinos. Revista Brasileira de Zootecnia, v.31, n.2, p.716-723, 2002.

FREITAS, D.; BERCHIELLI, T.T.; SILVEIRA, R.N. et al. Consumo e digestibilidade aparente total e parcial de rações com cana-deaçúcar, casca e raspa de mandioca ensiladas com polpa cítrica. Revista Brasileira de Zootecnia, v.31, n.3, p.1531-1542, 2002. (supl.)

KAWASHIMA, T. Role of native ruminants in establishment of sustainable agricultural systems in northeast Thailand 
Available at: <http://ss.jircas.affrc.go.jp/kanko/working\%20report/ No.30/30-01-10.pdf $>$. Accessed on: May 26, 2004.

KEARL, L. Exigências nutricionais dos bubalinos. In: RAMOS, A.A. (Ed.) Contribuição aos estudos dos bubalinos. Botucatu, 2003. p.47-90.

KEWALRAMANI, N.; GUPTA, B.N. Effect of level of protein on bacterial production rates in the rumen of buffalo calves. Journal Nuclear Agricultural Biology, v.16, p.40-44, 1987.

KURAR, C.K.; MUDGAL, V.D. Maintenance requirements for protein in buffaloes. Indian Journal of Animal Science, v.51, n.6, p.817-823, 1981

LEÃO, M.I.; VALADARES FILHO, S.C.; AZEVEDO, J.A.G. et al. Técnica de coleta de digesta omasal para estudos de digestão parcial em bovinos. In: REUNIÃO DA SOCIEDADE BRASILEIRA DE ZOOTECNIA, 39., Recife, 2002. Anais... Recife: SBZ, 2002. (CD-ROM).

LICITRA, G.; HERNANDEZ, T.M.; VAN SOEST, P.J. Standardization of procedures for nitrogen fractionation of ruminant feeds. Animal Feed Science and Technology, v.57, n.4, p.347-358, 1996.

MAEDA, E.M.; ZEOULA, L.M.; GERON, L.J.V. et al. Digestibilidade e características ruminais de dietas com diferentes teores de concentrado para bubalinos e bovinos. Revista Brasileira de Zootecnia, v.36, n.3, p.716-726, 2007

MAEDA, E.M.; ZEOULA, L.M.; JOBIM, C.C. et al. Chemical composition, fermentation, in vitro digestibility and in situ degradability of sugar cane silages with Lactobacillus, urea and agricultural byproduct. Revista Brasileira de Zootecnia, v.40, n.12, p. 2866-2977, 2011

MAENG, W.J.; BALDWIN, R.L. Dynamics of fermentation of purified diet and microbial growth in the rumen. Journal of Dairy Science, v.54, p.636-642, 1976

McDONALD, P.; HENDERSON, A.R.; HERON, S.J.E. The biochemistry of silage. 2.ed. Merlow: Chalcomb publications, 1991. 340p

MEHREZ, A.Z.; ØRSKOV, E.R. A study of the artificial fibre bag technique for determining the digestibility of feeds in the rumen. Journal of Agricultural Science, v.88, n.3, p.645-650, 1977

NATIONAL RESEARCH COUNCIL - NRC. Nutrient requeriments of beef cattle. Washington, D.C.: 1996. 242p

NUSSIO, L.G.; SCHMIDT, P.; Tecnologia de produção e valor alimentício de silagens de cana-de-açúcar. In: SIMPÓSIO SOBRE PRODUÇÃO E UTILIZAÇÃO DE FORRAGENS CONSERVADAS, 2., 2004. Maringá. Anais... Maringá:UEM/CCA/DZO, 2004. p.1-33.

PALMIQUIST, D.; CONRAD, H. Origin of plasma fatty acids in lactating cows fed high fat diets. Journal of Dairy Science, v.74, p.3152, 1971

PEREIRA, E.S.; QUEIROZ, A.C.; PAULINO, M.F. et al. Determinação das frações protéicas e de carboidratos e taxas de degradação in vitro da cana-de-açúcar, da cama de frango e do farelo de algodão. Revista Brasileira de Zootecnia, v.29, n.6, p.1887-1893, 2000.

PRADHAN, K.; BHATIA, S.K.; SANGWAN, D.C. Feed consumption pattern, ruminal degradation, nutrient digestibility and physiological reactions in buffalo and cattle. Indian Journal of Animal Sciences, v.67, n.2, p.149-151, 1997

PRADO, O.P.; ZEOULA, L.M.; MOURA, L.P.P et al. Efeito da adição de própolis e monensina sódica na digestibilidade e características ruminais em bubalinos alimentados com dieta à base de forragem. Revista Brasileira de Zootecnia, v.39, n.9, p.2055-2065, 2010.

RANJHAN, S.K.; SANGWAN, D.C.; BHATIA, S.K. et al. Intraruminal metabolism and nutrient digestion in cattle and buffalo fed lowgrade roughages supplemented with protein sources. Indian Journal of Animal Science, v.63, n.5, p.561-565, 1993.

SATTER, L.D.; ROFFLER, R.E. Relationship between ruminal ammonia and nonprotein nitrogen utilization by ruminants. 1. Development of a model for predicting nonprotein nitrogen utilization by catte. Journal of Dairy Science, v.58, n.12, p.1880-1888, 1975.
SILVA, D.J.; QUEIROZ, A.C. Análise de alimentos (métodos químicos e biológicos). 3.ed. Viçosa, MG: UFV, 2002. 235p.

SILVA, S.C. A cana-de-açúcar como alimento volumoso suplementar In: PEIXOTO, A.M.; MOURA, J.C.; FARIA, V.P. (Eds.) Volumosos para bovinos. Piracicaba: FEALQ, 1993. p.59-74

SINGH, S.; PRADHAN, K.; BATHIA, S.K. Relative ruminal microbial profile of cattle and buffalo fed wheat straw-concentrate diet Indian Journal Animal Science, v.62, n.12, p.1197-1202, 1992.

SIVKOVA, K.; TRUFCHEV, H.; VARLIAKOV, I. Comparative studies on fermentation processes in the rumen and blood content of calves and buffalo calves I. Effect on diet, containing alfafa haylage. In: WORLD BUFFALO CONGRESS, 5., 1997, Italia. Proceedings.. Itália: 1997. p.312-316

SNIFFEN, C.J.; O'CONNOR, J.D.; Van SOEST, P.J. et al. A net carbohydrate and protein system for evaluating cattle diets: II Carbohydrate and protein avaiability. Journal of Animal Science, v.70, n.10, p.3562-3577, 1992.

SOUZA, N.H.; FRANZOLIN, R.; RODRIGUES, P.H.M. et al. Efeitos de níveis crescentes de fibra em detergente neutro na dieta sobre a digestão ruminal em bubalinos e bovinos. Revista Brasileira de Zootecnia, v.29, n.5, p.1565-1577, 2000.

THANH, V.T.K.; ØRSKOV, E.R. Causes of differences in urinary excretion of purine derivatives in buffaloes and cattle. British Society of Animal Science, v.82, p.355-358, 2006.

THIAGO, L.R.L.S.; VIEIRA, J.M. Cana-de-açúcar: uma alternativa de alimento para a seca. Available at: $<\mathrm{http}$ ://www.cnpgc.embrapa.br/ publicacoes/cot/COT73.html>. Accessed on: Aug. 29, 2006.

UDEN, P.; COLUCCI, P.E.; VAN SOEST, P.J. Investigation of chromium, cerium and cobalt as markers in digesta. Rate of passage studies. Journal of the Science of Food and Agriculture, v.31, n.10, p.625-635, 1980.

USHIDA, K.; LASSALAS, B.; JOUANY, J.P. Determination of assay parameters for RNA analysis in bacterial and duodenal samples by spectrophotometry. Influence of smple treatment and preservation. Reproduction Nutrition Development, v.25, p.1037-1048. 1985.

VALADARES FILHO, S.C.; PINA, D.S. Fermentação ruminal. In: BERCHIELLI, T.T.; PIRES, A.V.; OLIVEIRA, S.G. (Orgs.). Nutrição de ruminantes. Jaboticabal: Funep, 2006. v.1, p.151-182.

VAN SOEST, P.J. Nutritional ecology of the ruminant. 2.ed. London: Comstock Publishing Associates, 1994. 476p.

VAN SOEST, P.J.; JONES, L.H.P. Effect of silica in forage upon digestibility. Journal of Dairy Science, v.51, n.10, p.1644-48, 1968.

VAN SOEST, P.J.; WINE, R.H. The determination of lignin and celullose in acid-detergent fibre with permanganate. Journal of Association Official Analysis Chemistry, v.51, n.4, 1968.

VAN SOEST, P.J.; ROBERTSON, J. B.; LEWIS, B. A. Methods for dietary fiber, neutral detergent fiber, and nonstarch polysaccharides in relation to animal nutrition. Journal of Dairy Science, v.74, n.12, p.3583-3597, 1991

VIEIRA, P.F. Efeito do formaldeído na proteção de proteínas e lipídios em rações para ruminantes. 1980. 98f. Tese (Doutorado em Zootecnia) - Universidade Federal de Viçosa, Viçosa, MG

VILELA, M.S.; FERREIRA, M.A.; VERÁS, A.S.C. et al. Avaliação de diferentes suplementos para vacas mestiças em lactação alimentadas com cana-de-açúcar: desempenho e digestibilidade. Revista Brasileira de Zootecnia, v.32, n.3, p.768-777, 2003.

ZAMBOM, M.A.; SANTOS, G.T.; MODESTO, E.C. et al. Valor nutricional da casca do grão de soja, farelo de soja, milho moído e farelo de trigo para bovinos. Acta Scientiarum. Animal Sciences, v.23, n.4, p.937-943, 2001.

ZEOULA, L.M.; BELEZE, J.R.F.; PRADO, I.N. et al. Inclusão de ionóforo ou probiótico em rações com $50 \%$ de volumoso e $50 \%$ de concentrado para bovinos e bubalinos: parâmetros ruminais In: SIMPÓSIO DE BÚFALOS DE LAS AMÉRICAS, 3.; BUFFALO SYMPOSIUM OF THE EUROPE AND AMERICAS, 2., 2006 , Medellín. Anais... Medellin, 2006. p.258. 